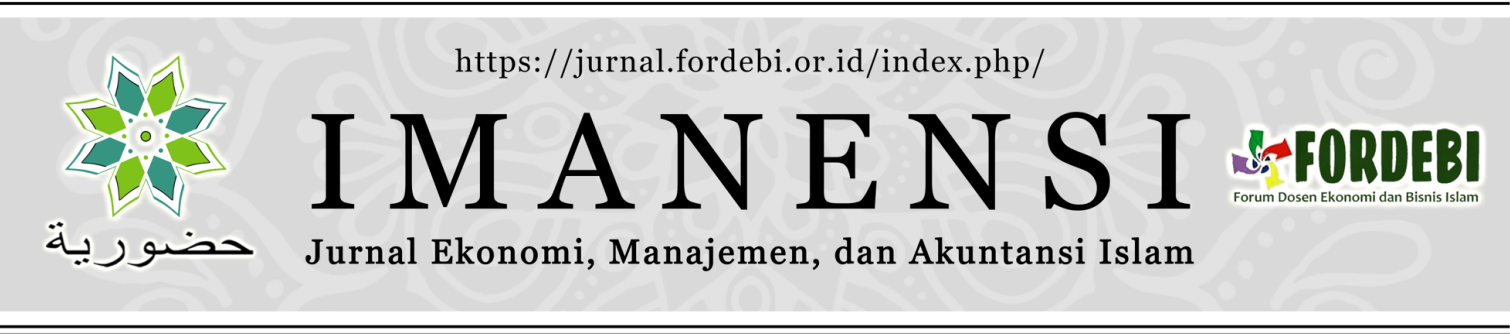

\title{
PERAN KOMUNIKASI E-WORD OF MOUTH TERHADAP VISIT INTENTION OBJEK WISATA
}

\author{
Mokhamad Favian Rizki Pratamaa,1, Erna Andajanib,2*, Siti Rahayuc,3 \\ a,b,c Universitas Surabaya, Jl. Raya Rungkut, Kali Rungkut, Surabaya 60293 Indonesia \\ afaviantama@yahoo.com; bernajani@staff.ubaya.ac.id*; cSitirahayu151@gmail.com \\ ${ }^{*}$ Corresponding author
}

\section{INFO ARTIKEL}

\section{IMANENS}

Volume 6

Nomor 2

Halaman 117-124

Malang, September 2021

ISSN: 2339-1847

e-ISSN: 2683-9968

\section{Kronologi Artikel:}

Tanggal Masuk:

21 April 2021

Tanggal Revisi:

8 September 2021

Tanggal Diterima:

10 September 2021

\section{Kata Kunci:}

Attitude toward city;

City image:

Instagram

Pariwisata

Visit intention.

\section{Keywords:}

Attitude toward city;

City image;

Instagram

Tourism;

Visit intention.

\begin{abstract}
Abstrak: Peran Komunikasi e-Word of Mouth terhadap Visit Intention Objek Wisata. Penelitian ini bertujuan mengetahui peran e-WOM (Instagram) terhadap Visit Intention obyek wisata di Surabaya yang dipengaruhi oleh attitude toward behavior dan destionation image. Metode penelitian menggunakan SEM (Structural Equation Modeling) dengan jumlah sampel sebanyak 150 responden yang aktif menggunakan Instagram. Penelitian ini menunjukkan e-WOM melalui Instagram berperan penting terhadap visit intention objek wisata karena menimbulkan persepsi yang sangat baik bagi wisatawan lainnya dan membentuk image Surabaya adalah destinasi wisata yang menyenangkan. Kondisi ini menimbulkan persepsi positif bagi wisatawan lainnya mengenai Surabaya.
\end{abstract}

\begin{abstract}
The Role of e-Word of Mouth Communication on Visit Intention of Tourist Attractions. This study aims to determine the role of e-WOM (Instagram) on the visit intention of tourism objects in Surabaya which is influenced by attitude toward behavior \& destination image. The research method uses SEM (Structural Equation Modeling) with a sample of 150 respondents who actively use Instagram. This study shows that e-WOM through Instagram plays an important role in the visit intention of tourist objects because it creates a very good perception for other tourists and forms the image of Surabaya as a pleasant tourist destination. This condition creates a positive perception for other tourists about Surabaya.
\end{abstract}

Disitasi sebagai: Pratama, MFR., Andajani, E \& Rahayu, S. (2001). Peran Komunikasi e-Word of Mouth terhadap Visit Intention Objek Wisata. IMANENSI: Jurnal Ekonomi, Manajemen, dan Akuntansi Islam, 6(2), 117-124. https://doi.org/10.34202/imanensi.6.2.2021.117-124.

\section{PENDAHULUAN}

Industri pariwisata merupakan salah satu industri terbesar di dunia yang akan terus bertumbuh dan sektor penting dalam perkembangan suatu wilayah atau negara. Selain itu dari segi moneter ekonomi, pariwisata dapat memasarkan pemandangan dan hasil budaya manusia, mengubah kawasan-kawasan dan masyarakat-masyarakat dunia menjadi produk wisata (Picard, 2006). Word of Mouth (WOM) adalah media yang paling sering digunakan untuk menyebarkan informasi 
dan mengkomunikasikan produk dan jasa antara orang yang dianggap independen dari perusahaan tersebut. WOM telah terbukti sebagai salah satu sumber informasi yang paling penting dari wisatawan (Ye et al., 2011). Kekuatan WOM telah diteliti selama beberapa dekade dalam literatur pemasaran. Internet saat ini telah berkembang menjadi sebuah sumber ataupun tempat berlangsungnya komunikasi electronic Word-of-Mouth atau WOM elektronik di kalangan pelanggan (Jalilvand dan Samiei, 2012). e-WOM meliputi berbagai media dan jenis situs web secara online, konsumen meberikan ulasan dalam bentuk postingan di internet sehingga ulasan tersebut secara signifikan mempengaruhi popularitas dan penjualan suatu produk dan jasa.

Informasi dari pengiklanan e-WOM memiliki efek signifikan terhadap perilaku wisatawan untuk mengunjungi suatu destinasi (Jalilvand dkk., 2012), dilain sisi wisatawan dapat menggunakan e-WOM pada berbagai tahap dalam pengambilan keputusan perjalanan (Christy dan Dimple, 2012). Perilaku wisatawan terhadap kota wisata mempunyai hubungan pengaruh signifikan terhadap niat berkunjung (Jalilvand dkk, 2012), jika citra kota pariwisata lebih kuat dan menonjol dibanding kota lain, maka dapat menjamin wisatawan akan mengunjungi suatu destinasi tersebut (Lopes, 2011). Wisatawan dalam mengambil keputusan tujuan wisata dipengaruhi oleh image atau citra tempat wisata tersebut. Destination image menjadi bagian dari proses seleksi tujuan wisata yang penting bagi konsumen, karena destination image dapat memberikan gambaran tempat wisata tersebut di pikiran wisatawan dan di dunia pariwisata. Sumber informasi wisatawan yang paling penting salah satunya adalah WOM (Ye dkk, 2011)

Penelitian ini merupakan replikasi Doosti dkk (2016) mengenai pengaruh eWOM terhadap niat berkunjung yang dipengaruhi oleh attitude toward dan image yang menunjukkan komunikasi e-WOM memiliki dampak positif terhadap attitude wisatawan, image wisata, dan niat untuk berkunjung ke destinasi wisata tersebut. Menurut Luo dan Zhong (2015) e-WOM sebagai sumber informasi menunjukkan perbedaan yang cukup besar dibandingkan dengan sumber lain, seperti aksesibilitas, kenyamanan, real-time layanan informasi, dan komunikasi interaktif. Fitur-fitur ini membuat e-WOM informasi sumber tunggal layak analisis mendalam. Pandangan bahwa e-WOM merupakan sumber informasi yang mungkin baik mengurangi pentingnya sumber-sumber lain (Baber dkk, 2016; Marchanda dan Hennig-Thurau, 2013).

Merujuk pada artikel penelitian Doosti dkk (2016) menyatakan bahwa masih sedikit penelitian tentang pengaruh e-WOM yang fokus pada produk pariwisata dan jasa. Belum banyak pula penelitian yang menguji pengaruh e-WOM terhadap city image. Hal ini merupakan peluang untuk menguji model penelitian tersebut pada kota pariwisata lainnya. Sehingga menarik untuk meneliti lebih lanjut mengenai pengaruh e-WOM (media sosial Instagram) terhadap niat untuk berkunjung ke Surabaya. Dipilihnya Surabaya karena merupakan kota wisata di Indonesia yang memiliki berbagai macam jenis wisata. Hal ini dapat tercermin dalam 5 tahun terakhir, Surabaya telah mendapatkan berbagai macam penghargaan tingkat nasional maupun internasional terkait tata kelola kota dan kepariwisataan. Berdasarkan kondisi ini, tujuan penelitian ini adalah untuk menganalisis e-WOM (Instagram) terhadap attitude toward city, city image, intention to visit kota wisata di Surabaya.

\section{METODE}

Pendekatan dalam penelitian ini adalah kuantitatif dengan mengumpulkan data menggunakan metode survey melalui pengisian kuesioner. Penelitian ini terdiri dari 3 variabel eksogen dan 1 variabel endogen. Variabel eksogen terdiri dari e- 
WOM, attitude toward city dan city image. Serta variabel endogen yaitu visit intention. Adapun karakteristik target pupolasi adalah adalah wisatawan yang aktif menggunakan media sosial Instagram dan pernah membaca ulasan suatu destinasi wisata sebagai referensi dalam memilih destinasi wisata di Surabaya, berusia minimal 18 tahun, dan pendidikan minimal SMA atau sederajat. Teknik pengambilan sampel dalam penelitian ini adalah non-probability sampling dan jenis pengambilan sampel purposive sampling. Pengolahan data menggunakan Structural Equation Modelling (SEM) AMOS versi 22.

Pengolahan data menggunakan SPSS dilakukan untuk menguji reliabilitas dan validitas setiap pertanyaan pada kuesioner. Pengolahan ini menggunakkan data sebanyak 30 sampel. Hasil uji validitas dan realibilitas menunjukkan valid dan realiabilitas. Tahap berikutnya dilanjutkan dengan SEM AMOS 21 untuk model pengukuran (measurement model) untuk menghitung Construct Reliabilty (CR) dan Average Variance Extracted (AVE). Setelah perhitungan CR dan AVE dinyatakan valid dan reliabilitas, maka dilanjutkan ke uji model struktural.

\section{HASIL DAN PEMBAHASAN}

\subsection{Model Pengukuran}

Pendekatan yang digunakan untuk menilai sebuah model pengukuran adalah menghitung Construct Reliabilty dan Average Variance Extracted. Tabel 1 menunjukkan bahwa setiap indikator variabel memiliki nilai standard loading $>0.5$, sehingga dapat dikatakan memenuhi uji validitas dengan baik. Pada uji validitas ditunjukkan dengan perhitungan AVE dengan nilai uji validitas konvergen per indikator yang menunjukkan nilai standardized loading diatas 0.5. Uji reliabilitas digunakan untuk mengetahui kehandalan suatu hasil pengukuran relatif konsisten. Menurut Hair dkk, (2010, p.710) nilai construct reliability yang dapat diterima adalah $\geq 0.7$. Berdasarkan Tabel 2 dapat diketahui bahwa keempat variabel memiliki nilai construct reliability $\geq 0.7$, sehingga dapat dikatakan bahwa keempat konstruk penelitian yang digunakan sudah reliabel.

Tabel 1. Perhitungan AVE \& CR

\begin{tabular}{lccccc}
\hline Variabel & $\begin{array}{c}\text { Indikat } \\
\text { or }\end{array}$ & $\begin{array}{c}\text { Loading } \\
\text { s }\end{array}$ & $\begin{array}{c}\text { Std. } \\
\text { Loadings } \\
\text { kuadrat }\end{array}$ & $\begin{array}{c}\text { Construct } \\
\text { Reliability }\end{array}$ & AVE \\
\hline & EWOM1 & 0,857 & 0,734 & & \\
& EWOM2 & 0,845 & 0,714 & & \\
e-WOM about city & EWOM3 & 0,735 & 0,540 & 0,871 & 0,534 \\
& EWOM4 & 0,623 & 0,388 & & \\
& EWOM5 & 0,699 & 0,489 & & \\
& EWOM6 & 0,583 & 0,340 & & \\
\hline \multirow{5}{*}{ Attitude toward city } & ATT1 & 0,834 & 0,696 & & \\
& ATT2 & 0,870 & 0,757 & 0,871 & \\
& ATT3 & 0,789 & 0,623 & & \\
& ATT4 & 0,667 & 0,445 & & \\
City image & CI1 & 0,848 & 0,719 & & \\
& CI2 & 0,887 & 0,787 & 0,884 & \\
\hline Intention to visit & CI3 & 0,811 & 0,658 & & \\
\hline
\end{tabular}


Analisis Structural Model digunakan menguji pengaruh antar variabel atau uji hipotesis. Indikator suatu konstruk disyaratkan memiliki nilai estimate yang signifikan dengan nilai critical ratio lebih besar dari 1.96 atau nilai $p$-value lebih kecil dari sama dengan $0.05(5.0 \%)$. Hasil pengukuran model structural terlihat pada Gambar 1 Dan Tabel 3.

Tabel 2. Hasil Uji Kecocokan Model Pengukuran

\begin{tabular}{llll}
\hline \multicolumn{1}{c}{ Kriteria } & \multicolumn{1}{c}{ Hasil } & \multicolumn{1}{c}{ Nilai Kritis } & Evaluasi Model \\
\hline CMIN/DF & 1.656 & $\leq 2,00$ & Good Fit \\
RMSEA & 0.066 & $\leq 0,08$ & Good Fit \\
GFI & 0.871 & $\geq 0,90$ & Marginal fit \\
TLI & 0.941 & $\geq 0,90$ & Good fit \\
CFI & 0.952 & $\geq 0,90$ & Good Fit \\
\hline
\end{tabular}

Tabel 3. Hasil Uji Kecocokan Model Struktural

\begin{tabular}{lcll}
\hline Kriteria & Hasil & Nilai Kritis & Evaluasi Model \\
\hline CMIN/DF & 1.748 & $\leq 2,00$ & Good fit \\
RMSEA & 0.071 & $\leq 0,08$ & Good fit \\
GFI & 0.859 & $\geq 0,90$ & Marginal fit \\
TLI & 0.933 & $\geq 0,90$ & Good fit \\
CFI & 0.944 & $\geq 0,90$ & Good fit \\
\hline
\end{tabular}

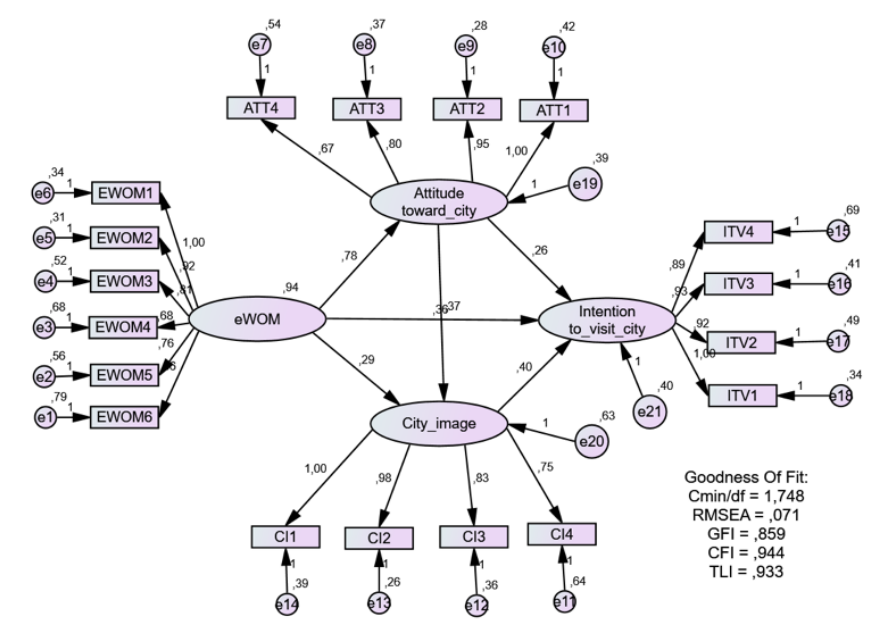

Gambar 1. Uji Model Struktural AMOS

\subsection{Pengaruh e-WOM terhadap Attitude Toward City}

Nilai estimate pengaruh e-WOM terhadap Attitude Toward City sebesar 0,782 dan critical ratio sebesar 9,011 (lihat Tabel 4). Kondisi ini menunjukkan bahwa eWOM berpengaruh terhadap Attitude Toward City. Hasil ini mendukung penelitian sebelumnya yang dilakukan Doosti dkk, (2016) yang mengatakan bahwa e-WOM berpengaruh positif terhadap Attitude Toward City. Penyebaran informasi melalui jejaring media sosial berhasil mempengaruhi sikap terkait kota Surabaya di benak masyarakat. Penelitian dari Park dan Lee (2009) mengatakan bahwa efek e-WOM yang bernada negatif khususnya pada produk yang menjual experiences berdampak lebih besar daripada e-WOM yang bernada positif. e-WOM yang bernada negatif akan menciptakan rasa kecemasan dan keraguan dari masyarakat terkait suatu 
destinasi wisata. Maka e-WOM bernada positif sangat diperlukan untuk menciptakan sikap yang positif dan menghindari hal tersebut. Sikap konsumen yang positif secara tidak langsung akan mempengaruhi konsumen lain sehingga menimbulkan perilaku berupa minat atau ketertarikan masyarakat untuk berkunjung dan berwisata ke kota Surabaya.

Tabel 4. Ringkasan Hasil Pengujian Hipotesis

\begin{tabular}{llllll}
\hline $\begin{array}{l}\text { Hubungan } \\
\text { Antar Konstruk }\end{array}$ & Estimate & C.R. & P & Keterangan \\
\hline EWOM $\rightarrow$ ATT & 0.782 & 9.011 & $* * *$ & Terdukung \\
EWOM $\rightarrow$ CI & 0.293 & 1.986 & 0.047 & Terdukung \\
EWOM $\rightarrow$ ITV & 0.359 & 2.768 & 0.006 & Terdukung \\
ATT $\rightarrow$ CI & 0.369 & 2.533 & 0.011 & Terdukung \\
ATT $\rightarrow$ ITV & 0.257 & 1.995 & 0.046 & Terdukung \\
CI $\rightarrow$ ITV & 0.397 & 4.389 & $* * *$ & Terdukung \\
\hline
\end{tabular}

\subsection{Pengaruh e-WOM terhadap City Image}

Hasil dari tabel 4 dapat diketahui bahwa nilai estimate pengaruh e-WOM terhadap City Image sebesar 0,293 dan critical ratio sebesar 1,986, yaitu e-WOM berpengaruh terhadap City Image. Hasil pengujian ini sesuai dan mendukung penelitian Doosti dkk, (2016) bahwa e-WOM berpengaruh positif terhadap City Image. Maka dapat disimpulkan bahwa penyebaran informasi elektronik melalui media sosial mampu memberikan gambaran yang cukup konkrit baik secara kognitif maupun afektif terhadap suatu kota yang akan menjadi destinasi wisatawan. Park dan Lee (2009) menjelaskan bahwa efek dari e-WOM bernada negatif jauh lebih berpengaruh daripada efek e-WOM yang bernada positif, khususnya terkait untuk produk yang menjual experiences atau pengalaman, eWOM yang bernada negatif akan menimbulkan persepsi negatif terkait citra suatu destinasi wisata. Citra negatif akan membuat wisatawan enggan untuk berkunjung pada destinasi tersebut. Sehingga citra yang positif sangat diperlukan untuk mempengaruhi konsumen supaya tertarik mengunjungi suatu destinasi wisata dalam hal ini yaitu kota Surabaya.

\subsection{Pengaruh e-WOM terhadap Intention to Visit}

Nilai pada tabel 4 mengenai pengaruh e-WOM terhadap Intention to Visit sebesar 0,359 dan critical ratio sebesar 2,768. Pengujian ini sejalan dengan hasil penelitian sebelumnya yang dilakukan oleh Doosti dkk, (2016). Penyebaran informasi elektronik melalui sosial media mampu menciptakan keinginan atau motivasi untuk mengunjungi suatu destinasi wisata tertentu. Beberapa user bahkan tidak ragu untuk merekomendasikan ke kerabat maupun masyarakat secara umum untuk mengunjungi destinasi tersebut melalui akun sosial media mereka. Hal ini bisa terjadi karena masyarakat merasa tempat tujuan tersebut menarik dan layak dikunjungi hanya berdasarkan informasi yang diterima melalui sosial media. Maka penyebaran informasi melalui sosial media sangat berpengaruh terhadap minat masyarakat untuk mengunjungi kota Surabaya.

\subsection{Pengaruh konstruk Attitude Toward terhadap City Image}

Pengaruh konstruk Attitude Toward terhadap City Image sebesar 0,369 dan critical ratio sebesar 2,533 pada tabel 4 dapat diartikan bahawa Attitude Toward City berpengaruh terhadap City Image serta mendukung hasil penelitian Doosti dkk, (2016) dan Hultman dkk (2015). Persepsi dan citra kota yang baik akan menciptakan pengaruh yang positif terkait dengan perilaku dan sikap masyarakat 
secara umum. Han dkk (2009) juga menjelaskan bahwa sikap masyarakat terhadap beberapa tempat mempengaruhi gambaran suatu kota secara keseluruhan. Jadi dapat disimpulkan bahwa konsep sikap masyarakat terhadap kota Surabaya dan citra kota Surabaya saling berkaitan satu sama lain.

\subsection{Pengaruh Attitude Toward terhadap Intention to Visit}

Pengaruh Attitude Toward terhadap Intention to Visit sebesar 0,257 dan critical ratio sebesar 1,995 dapat diartikan Attitude Toward City berpengaruh terhadap Intention to Visit (Tabel 4). Hasil pengujian ini mendukung penelitian Doosti dkk (2016) dan Jalilvand dkk (2013). Jalilvand et al. (2013) menyatakan bahwa sikap terhadap suatu kota wisata memiliki pengaruh yang signifikan terkait minat atau motivasi wisatawan untuk mengunjungi destinasi tertentu. Semakin positif sikap masyarakat terhadap kota Surabaya maka semakin tinggi kemungkinan kota Surabaya akan dikunjungi oleh wisatawan.

\subsection{Pengaruh konstruk antara City Image dengan Intention to Visit}

Nilai estimate pengaruh konstruk antara City Image dengan Intention to Visit pada Tabel 4 adalah sebesar 0,397 dan critical ratio sebesar 4,839. Hal ini dapat diartikan City Image berpengaruh terhadap Intention to Visit serta mendukung penelitian yang telah dilakukan oleh Doosti dkk, (2016). Lopes (2011) menyebutkan dalam penelitiannya sebuah kota wisata yang memiliki citra positif dan lebih menonjol dibandingkan dengan yang lain akan memberikan jaminan kesejahteraan dan kenyamanan bagi para wisatawan, maka peluang destinasi tersebut untuk dikunjungi akan semakin besar. Citra kota Surabaya yang positif terus digencarkan oleh masyarakat dan pemerintah melalui jaringan sosial media, dan hal ini terbukti melalui komentar-komentar, likes dan share yang dilakukan oleh banyak user Instagram. Hal ini akan meningkatkan minat dan motivasi masyarakat untuk mengunjungi kota Surabaya.

\section{SIMPULAN}

Hasil penelitian menunjukkan dengan banyaknya unggahan maupun komentar positif mengenai destinasi Surabaya di Instagram menimbulkan persepsi yang sangat baik bagi wisatawan lainnya dan membentuk image Surabaya adalah destinasi wisata yang menyenangkan, selanjutnya mendapatkan balasan komentar dari wisatawan lain yang mengatakan akan mengunjungi Surabaya. Kondisi ini menimbulkan persepsi positif bagi wisatawan lainnya mengenai Surabaya. City Image mengenai destinasi Surabaya yang menarik, variatif, pemandangan kota yang indah, maupun daya tarik alami dan sejarahnya menimbulkan keinginan wisatawan lain untuk mengunjungi Surabaya.

Saran untuk penelitian yang lebih lanjut dapat menguji model penelitian yang ada pada ini dengan menggunakan obyek penelitan berbeda. Pada penelitian ini menggunakan salah kota wisata yang ada di Jawa Timur, maka berikutnya dapat menggunakan obyek kota dengan image yang bukan kota wisata, seperti kota bisnis, kota pemerintahan atau kota pelajar. Hal ini bertujuan untuk memperkuat hubungan pengaruh antar variabel yang diujikan.

\section{REFERENSI}

Baber, A., Thurasamy, R., Malik, M.I., Sadiq, B., Islam, S. and Sajjad, M. (2016), Online word-of-mouth antecedents, attitude and intention-to-purchase electronic products in Pakistan, Telematics and Informatics, 33(2): 388-400. 
Christy, M.K.Ch. and Dimple, R.Th. (2012), The impact of electronic word-of-mouth communication: a literature analysis and integrative model, Journal of Decision Support Systems, 54(1):461-70.

Doosti, Shabnam et al., (2016), Analyzing the influence of electronic word of mouth on visit intention: the mediating role of tourists' attitude and city image, International Journal of Tourism City, 2(2):137 - 148

Hair, J. F., Black, W. C., Babin, B. J., dan Anderson, R. E., (2010), Multivariate Data Analysis: A Global Perspective, 7th edition, New Jersey: Pearson Prentice Hall

Han, H., Hsu, L.-T. and Lee, J.-S. (2009), Empirical investigation of the roles of attitudes toward greenbehaviors, overall image, gender, and age in hotel customers' eco-friendly decision making process, International Journal of Hospitality Management, 28 (4): 519-28.

Lopes, S.D.F. (2011), Destination image: origins, developments and implications, Pasos, 9 (2): 305-15.

Marchanda, A. and Hennig-Thurau, T. (2013), Value creation in the video game industry: industry economics, consumer benefits, and research opportunities, Journal of Interactive Marketing, 27 (3): 141-57

Park, C. and Lee, T. (2009). Information direction, website reputation and e-WOM effect: a moderating role of product type. Journal of Business Research, 62(1): 61-75

Ye, Q., Law, R., Gu, B. and Chen, W. 2011. The influence of user-generated content on traveler behavior: an empirical investigation on the effects of e-word-ofmouth to hotel online bookings. Computers in Human Behavior, 27 (2): 634-9. 
Halaman ini sengaja dikosongkan 